\title{
SYMPOSIUM ON THE SOUTH CHINA SEA ARBITRATION
}

\section{THE SOUTH CHINA SEA ARBITRATION: INNOVATIONS IN MARINE ENVIRONMENTAL FACT-FINDING AND DUE DILIGENCE OBLIGATIONS}

\author{
Makane Moïse Mbengue*
}

\section{Introduction}

The South China Sea Arbitration ${ }^{1}$ is a leading case in a new generation of environmental disputes, namely, environmental disputes that occur in disputed territorial or maritime areas. The dispute between the Philippines and China before the United Nations Convention on the Law of the Sea (UNCLOS) Annex VII Tribunal (the Tribunal) dealt in significant part with the Philippines' allegations of environmental violations by China. The Philippines asserted that China tolerated harmful fishing practices and proceeded with harmful construction activities, and that both caused serious harm to the marine environment of the South China Sea.

The semi-enclosed South China Sea is characterized by the extreme sensitivity and fragility of its ecosystems, and is one of the most important reservoirs of biodiversity in the world. ${ }^{2}$ In this context, the Tribunal expressed itself to be "particularly troubled" 3 by certain environmental concerns. This led the Tribunal to opt for a high degree of vigilance not only in the assessment of the actual harm but also in the prevention of continuing harm to the South China Sea.

This vigilance can be perceived at two primary levels: first, at the level of the policy that the Tribunal develops on due diligence (part 1); and, second, at the level of the process put forward by the Tribunal with respect to expertise (part 2).

Back to the Basics: International Environmental Law as the Yardstick of Due Diligence in the Context of the Law of the Sea

The Tribunal in the South China Sea Arbitration espouses an expansive approach to due diligence in the context of the law of the sea. It thereby contributes to the practical operation of due diligence in international law in general and for Part XII of UNCLOS in particular. It insists that a strong "level of vigilance" 4 is required under Part XII of UNCLOS. What makes the contribution of the South China Sea Arbitration even

* Associate Professor of International Law, Faculty of Law University of Geneva and Affiliated Professor, Sciences Po Paris (School of Law).

Originally published online 12 December 2016.

1 The South China Sea Arbitration (Phil. v. China), PCA Case No. 2013-19, Award (July 12, 2016) [hereinafter Final Award]. For an overview of the Award see Lucy Reed \& Kenneth Wong, Marine Entitlements in the South Cbina Sea: The Arbitration Between the Philippines and China, 110 AJIL (forthcoming 2016).

2 Final Award, supra note 1, at paras. 823-825.

3 Id. at para. 957.

${ }^{4} \underline{I d}$. at para. 961. 
more unprecedented is the high standard of due diligence that the Tribunal deduces from Part XII of the Convention by using a systemic approach to treaty interpretation. The use of a systemic approach leads the Tribunal to read relevant provisions of UNCLOS-in particular Article 192 (which provides for the "obligation to protect and preserve the marine environment") - in light of other UNCLOS provisions and, most important, in light of "the corpus of international law relating to the environment." It is by reference to this interaction among environmental provisions that the Tribunal is able to define a very high standard of due diligence in Part XII of UNCLOS.

This differs strikingly from the approach adopted, for example, by the UNCLOS Seabed Disputes Chamber. The latter has underlined that "the standard of due diligence has to be more severe for the riskier activities." Therefore, the Seabed Disputes Chamber has made the high standard of due diligence a question of fact more than a question of law: the riskier an activity, the more due diligence would be required. By contrast, the Tribunal's systemic approach to treaty interpretation in the South China Sea Arbitration makes the high standard of due diligence more of a question of law. It is not per se the risky character of the Chinese activities or the activities of Chinese flag vessels that determine the level of due diligence, it is the rules of UNCLOS read as a whole and in light of the "corpus of international law relating to the environment" that require such a high degree of due diligence with respect to the marine environment.

To illustrate, the Award reveals that the Tribunal infers the duty of due diligence to prevent the harvest of endangered species "from Article 192 (of UNCLOS), read against the background of other applicable international law." The Tribunal, in particular, makes an explicit renvoi to the Convention on the International Trade in Endangered Species of Wild Fauna and Flora which in its view "forms part of the general corpus of international law that informs the content of Article 192" of UNCLOS, in order to conclude that Article 192 includes "a due diligence obligation to prevent the harvesting of species that are recognised internationally as being at risk of extinction and requiring international protection.".

The South China Sea Arbitration demonstrates, therefore, that the normative sophistication or diversification of international environmental law is a source of richness for the standard of due diligence under general international law. International environmental law feeds the law of the sea by giving a "particular shape" to the duty of due diligence under Part XII of UNCLOS.

In turn, the law of the sea allows international environmental law to be more effective by insisting on the "enforcement" dimension of due diligence. The Tribunal's incursive strategy is noteworthy when dealing with the obligation to conduct an Environmental Impact Assessment (EIA) as part of the due diligence obligation under general international law. The Tribunal goes so far as to assess whether China had enforced its own legislative standards regarding an EIA.

Even more remarkable is the (discreet) attempt by the Tribunal to create a hierarchy among the different characteristics and components of an EIA. In the Pulp Mills case, the International Court of Justice was more hesitant and preferred to underline that general international law does not specify the scope and content of an EIA. The Court considered "that it is for each State to determine in its domestic legislation or in the authorization process for the project, the specific content of the environmental impact assessment required in each case." 10 Despite agreeing with the rationale of the ICJ, the Tribunal in the South China Sea Arbitra-

${ }^{5} \underline{I d}$. at para. 941 .

${ }^{6}$ Responsibilities and Obligations of States Sponsoring Persons and Entities with respect to Activities in the Area (Request for Advisory Opinion submitted to the Seabed Disputes Chamber), Case No. 17, Advisory Opinion 43, para. 117 (Feb. 1, 2011).

${ }^{7}$ Final Award, supra note 1, at para. 959.

${ }^{8} \underline{I d}$. at para. 956.

${ }^{9} \underline{I d}$. at 959 .

${ }^{10}$ Pulp Mills on the River Uruguay (Arg. v. Uru.), 2010 ICJ ReP. 2010 14, 83, para. 205 (Apr. 20). 
tion seems to have singled out "comprehensiveness" as the most important characteristic of an EIA. Indeed, it emphasizes that not only did the alleged Chinese EIAs not comply with the standards under Chinese Law but they were also "far less comprehensive than EIAs reviewed by other international courts and Tribunals." The Tribunal does not explain, though, what "comprehensiveness" means and to which "international courts and Tribunals" it is referring-besides a quick reference to the Pulp Mills case in a footnote. This shows that notwithstanding its expansive and progressive approach to due diligence, the South China Sea Arbitration Award has some grey areas.

For instance, the Award is inconclusive with respect to principles of customary international environmental law that could also have informed the scope of due of diligence within Part XII of UNCLOS. Of particular importance is the conspicuous lack of any mention of the precautionary approach/principle in the Award. This is in spite of the fact that the Philippines claimed that China was obliged to apply the precautionary approach in the context of Part XII of UNCLOS - even if at the same time and for strategic reasons, the Philippines asserted that it was "not necessary to the Tribunal's findings in the current case because the risks to the marine environment are obvious and there can be no uncertainty." 12 The facts show that not everything was obvious and that the Tribunal could therefore have made better use of the precautionary approach for certain issues. But perhaps, such use was preempted ab initio if we take into account the approach to scientific expertise that the Tribunal develops.

\section{"Go, I do not disdain you":" ${ }^{13}$ Scientific Experts and the South China Sea Arbitration}

The Tribunal's vigilance with regard to the environment in the South China Sea Arbitration can also be perceived at the level of the judicial process. In particular, the Tribunal was very "diligent" in using scientific experts not only to gather evidence in what is to a certain extent a complex environmental dispute, but also to understand the complexity, interdependence, and interconnectedness that characterize the South China Sea and its ecosystems. The Tribunal, thus, appointed its own experts (ex curia experts) in order to have, in its own words, "independent opinion(s)"14 on the environmental impact of China's construction activities in the South China Sea and also on technical matters raised by the Philippines' pleadings.

If the recourse to ex curia experts is rare in international adjudication, what is even more exceptional in the South China Sea Arbitration is the rather unusual and sophisticated procedure that the Tribunal put in place to appoint its experts. A specific Rule-Rule 24-was incorporated into the Rules of Procedure of the Tribunal. ${ }^{15}$ Rule 24 like the other Rules of Procedure was elaborated pursuant to Article 5 of Annex VII to UNCLOS which provides that "[u]nless the Parties to the dispute otherwise agree, the Arbitral Tribunal shall determine its own procedure." Rule 24 was inspired by Article 29 of the 2013 UNCITRAL Arbitration Rules. Rule 24 goes well beyond the traditional rules on experts before international courts and tribunals, such as the rules in the Statute and Rules of the ICJ and the Statute and Rules of the ITLOS. Rule 24 also goes well beyond certain recent practices that have been developed with respect to scientific experts, such as the procedure that the ICJ set forth in the Whaling case. ${ }^{16}$ In this sense, the South China Sea Arbitration reveals that

${ }^{11}$ Final Award, supra note 1, at para. 990.

$12 \underline{I d}$. at para. 910 .

13 Pierre Corneille, The Cid (2005).

${ }^{14}$ Final Award, supra note 1, at paras. 84, 136, and 821.

15 The South China Sea Arbitration (Phil. v. China), PCA Case No. 2013-19, Rules of Procedure (Aug. 27, 2013).

${ }_{16}$ On the issue of experts in the Whaling case, see Makane Moïse Mbengue, Scientific Fact-Finding at the International Court of Justice: An Appraisal in the Aftermath of the Whaling Case, 29 LEIDEN J. INT'L L. 529 (2016). 
there is room for procedural law-making and innovation with respect to the use of scientific experts in the system of international courts and tribunals.

Rule 24 emphasizes the need for transparency, independence, cooperation, and dialogue in the expert process before the Tribunal. It provides that the Tribunal can appoint one or more independent experts "after seeking the views of the parties." The said Rule also requires the experts to submit to the Tribunal and to the parties a description of their qualifications and a statement of their impartiality and independence. Parties can also raise any objections as to the expert's qualifications, impartiality or independence. Moreover, the Rule foresees the obligation for the Philippines and China to give the experts any relevant information or produce for their inspection any relevant documents or goods that they may require of them. The Rule goes as far as obliging the parties to afford the expert all reasonable facilities in the event that the expert's terms of reference contemplate a visit to the locations to which the case relates. (Such an obligation of cooperation with $e x$ curia experts would of course face practical limits in a case in which one of the parties has declined to appear.) Finally, the Tribunal is required to communicate a copy of the expert reports to the parties, and the latter are given the opportunity to express in writing their respective opinions on the reports. Thereafter the parties can also cross-examine the Tribunal's experts in a special hearing and the Tribunal can even pose questions to both ex curia experts and exparte experts (i.e. the parties' experts) during the hearing.

The Tribunal in the South China Sea Arbitration implemented an innovative procedure to assess and measure as precisely as possible the environmental situation within the disputed area. The Tribunal was not merely interested in facts; it needed "hard facts." 17 One could, thus, say that the South China Sea Arbitration gave birth to "hard fact finding." This strong concern for "hard facts" gave rise to a complex web of dialogue with and among experts during the proceedings. Inter-dialogue took place between the Tribunal and the ex parte experts. Intra-dialogue occurred between the Tribunal's experts and party-appointed experts. Extra-dialogue even took place as the Tribunal indirectly conveyed questions to experts that were not formally appointed by the Philippines but whose publications were quoted during the hearing on the merits. For instance, the Award indicates that "the Tribunal conveyed a request from Dr. Ferse [one of the Tribunal-appointed expert] to seek clarification from a scientist, Professor John McManus of the University of Miami, United States, whose studies had been cited during the Hearing on the Merits .... As a result of this process, Professor McManus provided the Tribunal with a revised version of his unpublished paper and reported that he had conducted further examinations, interviews, studies of satellite imagery, and an underwater inspection."18

This "informal" recourse to experts who are neither ex curia nor ex parte, is a feature of the South China Sea Arbitration, broadening and drawing new contours for the notion of expert use before international courts and tribunals.

Most important, the Tribunal gives scientific expertise a new function by making it a central tool for the sound administration of international justice and for ensuring equality between the parties to a dispute. Even when one party to a dispute does not appear-which was the case with China — an international court or tribunal must still ensure that the claims of the other party are well founded in fact and in law. The Tribunal in the South China Sea Arbitration was very concerned with being "vigilant with respect to establishing whether the Philippines' claims are well founded in fact and law." ${ }^{\prime 9}$ The intensive use of expert reports allowed the Tribunal to comprehensively assess the environmental situation within the South China Sea and to determine whether China's behavior constituted a breach of the general obligation contained in Part XII of UNCLOS to protect and preserve the marine environment.

${ }^{17}$ Final Award, supra note 1, at para. 847.

${ }^{18} \underline{I d}$. at paras. 849-850.

${ }^{19} \underline{I d}$. at para. 15 . 
When the expert evidence was not convincing, the Tribunal did not make any finding. The following paragraph of the Award is noteworthy:

In contrast to the situations of harvesting of endangered species and harmful construction activities, there is scant evidence in the case record about the use of explosives and cyanide over the last decade or Philippine complaints about its use. This suggests China may have taken measures to prevent such practices in the Spratly Islands. In any event, the Tribunal is not prepared to make a finding on the evidence available ... with respect to cyanide and explosives. ${ }^{20}$

Here, the Tribunal not only declines to make any finding because of a lack of scientific evidence; it also goes as far as to presume that the lack of evidence entails that China has-perhaps-taken measures to prevent certain harmful fishing practices. In other words, whenever experts were not able to provide the Tribunal with "hard facts" regarding certain issues, the Tribunal would infer that it was probably because China was acting consistently with Part XII of UNCLOS. Thus, de facto, the Tribunal placed, to a certain extent and in certain parts of the Award, the burden of proof upon the experts.

In light of the above, some might criticize the Award in the South China Sea Arbitration as an instance of delegation —or abdication - of the international judicial function to experts. One can even wonder if the international judicial function authorizes an international tribunal to infer from the lack of expert evidence that a state is presumably complying with its international obligations under international law-particularly when the said state declined to appear and did not, thus, fully present its case.

On balance, however, such criticism of the South China Sea Arbitration does not seem justified. In carefully managing its strong reliance on experts, the Tribunal has shown that the effective use of experts better equips international courts and tribunals to deal with environmental disputes having complex scientific and technical aspects.

${ }^{20} \underline{I d}$. at para. 975. 